\title{
Glucose effect on degradation kinetics of methyl parathion by filamentous fungi species Aspergilus Niger AN400
}

\section{Efeito da glicose na degradação cinética de metil paration pela espécie fúngica Aspergillus niger AN400}

\begin{abstract}
Glória Marinho
Farmacêutica. Bioquímica. Doutora Hidráulica e Saneamento pela Escola de Engenharia de São Carlos da Universidade de São Paulo (EESC-USP). Professora do Departamento da Área de Química e Meio Ambiente e do Programa de Pós-Graduação em Tecnologia e Gestão Ambiental do Instituto Federal de Educação, Ciência e Tecnologia do Ceará (IFCE)
\end{abstract}

\section{Kelly Rodrigues}

Engenheira Civil. Doutora em Hidráulica e Saneamento pela EESC-USP. Professora do Departamento da Área de Química e Meio Ambiente e do Programa de Pós-Graduação em Tecnologia e Gestão Ambiental do IFCE

\section{Rinaldo Araujo}

Químico. Doutor em Química Inorgânica pela Universidade Federal do Ceará (UFC). Professor do Departamento da Área de Química e Meio Ambiente e do Programa de Pós-Graduação em Tecnologia e Gestão Ambiental do IFCE

\section{Zuleika Bezerra Pinheiro}

Tecnóloga em Gestão Ambiental e Mestranda do Programa de Pós-Graduação em Tecnologia e Gestão Ambiental do IFCE

\section{Germana Maria Marinho Silva}

Farmacêutica. Mestre em Tecnologia e Gestão Ambiental pelo IFCE. Professora do Departamento da Área de Química e Meio Ambiente do IFCE - Maracanaú

\begin{abstract}
This study evaluated the glucose effect on the removal of methyl parathion by Aspergillus niger AN400. The study was conducted in two stages: toxicity tests on plates and assays in flasks, under an agitation of $200 \mathrm{rpm}$. The methyl parathion concentrations in the toxicity test ranged from 0.075 to $60 \mathrm{mg} / \mathrm{L}$. The second stage consisted on evaluating reactors: six control reactors with methyl parathion solution; six reactors with fungi and methyl parathion, and six reactors containing fungi, methyl parathion, and glucose. The reaction times studied ranged from 1 to 27 days. Methyl parathion concentrations of up to $60 \mathrm{mg} / \mathrm{L}$ were not toxic for Aspergillus niger AN400. The first-order kinetic model served as a good representation of the methyl parathion conversion rate. The first-order kinetic constant was $0.063 \pm 0.005 h^{-1}$ for flasks without addition of glucose, while a value of $0.162 \pm 0.014 h^{-1}$ was obtained when glucose was added.
\end{abstract}

Keywords: Aspergillus niger; biological reactors; glucose; methyl parathion; toxicity.

\section{Resumo}

Este estudo avaliou o efeito da glicose na remoção de metil paration por Aspergillus niger AN400. O estudo foi realizado em duas etapas: testes de toxicidade em placas e ensaios em batelada, sob agitação de $200 \mathrm{rpm}$. As concentrações de metil paration no ensaio de toxicidade variaram de 0,075 a $60 \mathrm{mg} / \mathrm{L}$. A segunda etapa consistiu na avaliação dos reatores divididos em lotes: seis reatores controle, com solução de metil paration; seis reatores com fungos e paration metílico e seis reatores com fungos, paration metílico e glicose. Os tempos de reação estudados variaram de 1 a 27 dias. Concentrações de paration metílico de até $60 \mathrm{mg} / \mathrm{L}$ não foram tóxicas para Aspergillus niger AN400. O modelo de primeira ordem representou bem a cinética de degradação do metil paration. A constante cinética foi de $0,063 \pm 0,005 h^{\prime}$ para reatores sem adição de glicose, enquanto o valor de 0,162 $\pm 0,014$ h' foi obtido quando a glicose foi adicionada.

Palavras-chave: Aspergillus niger; reatores biológicos; glicose; metil paration; toxicidade. 


\section{Introduction}

The environmental contamination resulting from worldwide indiscriminate, abusive, and long-term use of pesticide is a cause of great concern to public authorities and health providers, for it seriously impacts the sustainability of natural resources and human health.

One of the consequences of the widespread use of pesticides in agriculture is the contamination of water bodies. The use of agrochemicals close to flooded areas has led to the intoxication of many fish species (ESPINDOLA et al., 2000). It represents a serious pollution problem that causes environmental imbalance and a high incidence of fish poisoning, which is harmful to aquatic and human life.

Several factors are directly related in the persistence and toxicity of these compounds in the environment, including soil and water mobility, half-life in soil and water, frequency of application, climatic conditions, and irrigation (SUDO et al., 2002).

According to the National Health Foundation of Brazil, about 400 compounds are applied in agriculture in the country, distributed among approximately 700 commercial brands.

Nevertheless, only 22 types of agrochemicals are listed in the water quality regulations for human consumption in Brazil. According to the Brazilian Industry National Union of Agricutural Defense (SINDAG, acronyms in Portuguese) products, the insecticides represent $25.9 \%$ of all agrochemicals marketed in Brazil. Ceará ranks third among Brazil's North-eastern states in the sale of agrochemicals (SINDAG, 2003), with methyl parathion ranking as the leading sold insecticide (AGRIPEC, 2000).

Organophosphorus methyl parathion (dimethyl para-nitrophenyl thiophosphate), which contains $600 \mathrm{~g} / \mathrm{L}$ of active constituent, is inflammable and noncorrosive. The National Sanitary Surveillance System (SNVS), under regulation N. 10/1985, classifies this product as highly toxic (AGRIPEC, 1987). Although its activity in the environment is short-lived and little dispersive, methyl parathion (MP) can be highly toxic for humans. Toxicity by this organophosphorate results from the inhibition of the enzyme acetylcholinesterase, which causes acetylcholine to be accumulated in the body, affecting the central nervous system and sometimes leading to fatal respiratory failure (HERNANDEZ et al., 1998). Despite these hazards, this pesticide is widely used in agriculture.

Several methods exist for removing agrochemicals from water, for example, degradation by ultraviolet radiation in the presence of humic acid (SANTOS, REZENDE, 1999), degradation by gamma-rays (LUCHINI et al., 1999), adsorption by activated coal fibers (MARTÍN-GULLÓN; FONT, 2001), manganese-catalysed ozonation (MA; GRAHAM, 2000), adsorption in organic clay (PAL; VANJARA, 2001), nanofiltration (BOUSSAHEL et al., 2000), and so on. However, these physical, chemical, and physicochemical methods are usually more costly than biological treatments.
Fungi have been employed extensively to remove toxic and recalcitrant compounds. Garcia et al. (2000) used the species Aspergillus niger, Aspergillus terreus and Geotrichum candidum in the removal of phenolic compounds; Volke-Spulveda et al. (2003) studied hexadecane biodegradation by Aspergillus niger; and Bruce et al. (1995) investigated the degradation of pentachlorophenol by the fungi species Phanerochaete chrisosporyum, Trametes versicolor and Inonotus dryophilus

Glucose addition is important to improve the efficiency of bioremediation of persistent compounds like dyes (YANG et al., 2008; RODRIGUES et al., 2010), phenols (RODRIGUES et al., 2007; SILVA et al., 2007) and pesticides (SAMPAIO, 2005; YANG et al., 2008). Singh (2006) reports that glucose addition produces substances of high reactivity, which react more easily with the pollutant.

This research focused on evaluating MP removal by Aspergillus niger in the presence and absence of glucose, and on estimating the biological degradation kinetics.

Glucose was chosen because it is a primary substratum and the main carbon source for this fungus.

\section{Material and methods}

\section{Insecticide}

The dimethyl para-nitrophenyl thiophosphate $600 \mathrm{~g} / \mathrm{L}$, MP, was supplied by AGRIPEC Química e Farmacêutica, in Fortaleza, state of Ceará.

\section{Cultivation and production of the fungus species}

Aspergillus niger AN400 was grown on Petri dishes at a temperature of $30{ }^{\circ} \mathrm{C}$, using Sabouraud Dextrose Chloramphenicol (ASDC) agar as the culture media (Acumedia, Baltimore), supplemented with $1 \mathrm{~mL}$ of Vishniac solution (g/L): EDTA (10.00), $\mathrm{ZnSO}_{4} .7 \mathrm{H}_{2} \mathrm{O}$ (4.40); $\mathrm{MnCl}_{2} \cdot 4 \mathrm{H}_{2} \mathrm{O}$ (1.00); $\mathrm{CoCl}_{2} \cdot 6 \mathrm{H}_{2} \mathrm{O}(0.32) ;\left(\mathrm{NH}_{4}\right)_{6} \mathrm{Mo}_{7} \mathrm{O}_{24} \cdot 4 \mathrm{H}_{2} \mathrm{O}$ (0.22); $\mathrm{CaCl}_{2} \cdot 2 \mathrm{H}_{2} \mathrm{O}(1.47)$ and $\mathrm{FeSO}_{4} .7 \mathrm{H}_{2} \mathrm{O}(1.00)$.

Aspergillus niger spores were removed from the Petri dishes with 4 $\mathrm{mL}$ of Tween 80 solution, and they were transferred to test tubes. For the spore count, a spore solution was prepared with $50 \mu \mathrm{L}$ of spores in suspension previously shaken in a Vortex shaker, and $950 \mu \mathrm{L}$ of Tween 80 solution, yielding a dilution of 1:20. $20 \mu \mathrm{L}$ of the prepared solution were then transferred to a $0.1 \mathrm{~mm}$ deep Neubauer chamber, with a minimum area of $1 / 400 \mathrm{~mm}^{2}$. The spore count was carried out using an optical microscope with $400 \mathrm{x}$ magnification in 16 fields.

\section{Toxicity test on Petri dishes}

Twenty Petri plates were prepared and divided into sets, using ASDC as the culture medium. The MP concentration ranged from 
0.075 to $60 \mathrm{mg} / \mathrm{L}$. The concentration of $A$. niger spores inoculated was $2 \times 10^{6} / \mathrm{mL}$. In order to choose the range of MP to be assayed, the minimum value detected by the MP determination method and the maximum solubility of MP in water ( $65 \mathrm{mg} / \mathrm{L})$ were considered. MP concentrations used in each set were (mg/L): 0.075, 0.0150, $0.300,0.750,1.500,3.500,7.500,15.000,30.000$ and 60.000 , respectively, for set $1,2,3,4,5,6,7,8,9$, and 10

\section{Culture}

Two were prepared culture media. The first (1) comprising a solution of distilled water and MP, $0.05 \mathrm{~g} / \mathrm{L}$ of chloramphenicol and $1 \mathrm{~mL} / \mathrm{L}$ of Vishniac solution; second and (2) by a solution of distilled water and MP, $0.5 \mathrm{~g} / \mathrm{L}$ of glucose, $0.05 \mathrm{~g} / \mathrm{L}$ of chloramphenicol and $1 \mathrm{~mL} / \mathrm{L}$ of Vishniac solution. All the culture mediums were previously autoclaved for 15 minutes at $121^{\circ} \mathrm{C}$ and $1.5 \mathrm{~atm}$. The choice of the glucose concentration was based on results reported in other research (SAMPAIO, 2005; PINHEIRO et al., 2010).

\section{Assays in batch reactors}

Eighteen Erlenmeyer flasks (250 mL) were used as reactors. They were sealed and divided into three sets. The first set consisted on six control reactors containing $100 \mathrm{~mL}$ of culture medium 1 (C), with different MP concentrations, while the second one consisted on six reactors containing $100 \mathrm{~mL}$ of culture medium, one with six different MP concentrations and two x $10^{6} \mathrm{~A}$. niger's spores $(\mathrm{PF})$, and the third set contained $100 \mathrm{~mL}$ of culture medium 2 with six different MP concentrations and $2 \times 10^{6} \mathrm{~A}$. niger's spores (PFG). Table 1 presents the initial MP concentrations in each reactor.

All reactors were covered with black plastic bags and subjected to $200 \mathrm{rpm}$ shaking in the shaker used in the first stage. The temperature was kept at $30^{\circ} \mathrm{C}$ throughout the experiment.

The reaction times were: 1, 3, 6, 8, 10, 13, 22 and 27 days. The parameters analyzed were $\mathrm{pH}$, volatile suspended solids (VSS) and MP concentrations. Analyses were performed according to APHA (1995)

\section{Kinetic evaluation of MP degradation}

The effect of glucose on the pesticide degradation rate was evaluated though kinetic studies, using temporal profiles of MP concentration for each condition under study. The initial rate (Ro) was estimated at time zero by the mass balance equation for batch reactor (Equation 1)

$$
R o=-\frac{d C}{d t}
$$

Equation 1

Where:

$\mathrm{C}_{\mathrm{MP}}$ is the MP concentration and " $\mathrm{t}$ " is the time.

A kinetic model was adjusted to the Ro values as a function of the initial MP concentrations in the reactors. The Ro values were estimated, and the kinetic model was adjusted using LevenbergMarquardt's nonlinear regression method - Microcal Origin 5.0 (MARQUARDT, 1963).

\section{Analytical methods}

The MP was quantified using a Shimadzu Liquid Chromatograph (LC-10 AD), which was equipped with UV-visible diode array detector (SPD-10AVP), column oven (CTO -10AS), and a low-pressure pump system (SL - 10 AVP), operating with up to four solvents.

The insecticide was separated on a Supelco C18 column $(25 \mathrm{~cm}$ x 4,6 mm D.I; $5 \mu \mathrm{m}$ particles), under the following chromatographic conditions: isocratic system with a phase acetonitrile : water $-80 \%$ ( $1 \mathrm{~mL} / \mathrm{min}$ ), an initial run time of five minutes, detection at $270 \mathrm{~nm}$, and a $20 \mu \mathrm{L}$ injection volume.

The $\mathrm{pH}$ was determined using a Universal Indicator of $\mathrm{pH}$ 0-14 paper (Merck), and the VSS were quantified according to the Standard Methods for Examination of Water and Wastewater (APHA, 1995).

The samples for analysis, collected in a sterile atmosphere provided by a Bunsen burner, were poured into sterilized Ependorff flasks. The $\mathrm{pH}$ was determined at the moment of sampling, and the sample was refrigerated at $4{ }^{\circ} \mathrm{C}$ for subsequent determination of the MP concentration.

Table 1 - Initial concentrations of MP used assays in batch reactors of controls, PF e PFG

\begin{tabular}{|c|c|c|c|c|c|}
\hline Reactor & $\begin{array}{l}\text { Concentration of MP } \\
(\mathrm{mg} / \mathrm{L})\end{array}$ & Reactor & $\begin{array}{l}\text { Concentration of MP } \\
(\mathrm{mg} / \mathrm{L})\end{array}$ & Reactor & $\begin{array}{l}\text { Concentration of MP } \\
(\mathrm{mg} / \mathrm{L})\end{array}$ \\
\hline $\mathrm{C} 1$ & 0.14 & PF1 & 0.21 & PFG1 & 0.62 \\
\hline $\mathrm{C} 2$ & 0.91 & PF2 & 1.25 & PFG2 & 1.25 \\
\hline C3 & 2.68 & PF3 & 3.06 & PFG3 & 4.67 \\
\hline $\mathrm{C} 4$ & 5.62 & PF4 & 6.41 & PFG4 & 6.53 \\
\hline C5 & 11.32 & PF5 & 10.93 & PFG5 & 14.52 \\
\hline C6 & 20.99 & PF6 & 19.14 & PFG6 & 24.89 \\
\hline
\end{tabular}

C: controls reactors; PF: reactors with fungi and methyl parathion; PFG: reactors containing fungi, glucose, and methyl parathion. 
The VSS concentration was determined at the end of the experiment in all samples from the PF and PFG reactors.

\section{Results and discussion}

\section{Toxicity test on Petri plates}

A. niger spore growth was not observed in the Petri plates after 19 hours of incubation in the toxicity test. After 43 hours of incubation, mycelia had grown on the dishes containing MP concentrations of $0.075 ; 0.15 ; 0.30 ; 0.75 ; 1.50 ; 3.50$ and $7.50 \mathrm{mg} / \mathrm{L}$. No macroscopically visible alteration was found in the other concentrations. After 72 hours of incubation, most of the dishes contained A. niger spores on the surface except on the dish containing the $60 \mathrm{mg} / \mathrm{L}$ concentration, whose surface was not entirely covered with spores. However, the entire surface of this dish was covered with spores after 96 hours of incubation.

The International Programme of Chemical Safety (IPCS) - Health and Safety Guide (IPCS, 1992) states that microorganisms can use MP as a carbon source. Studies in natural communities have shown that MP concentrations of up to $5 \mathrm{mg} / \mathrm{L}$ increase the biomass and reproductive activity. Bacteria and actinomycetes responded satisfactorily, while filamentous fungi and yeasts were not capable of using MP. However, the toxicity dish test revealed that A. niger was able to grow with MP doses of up to $60 \mathrm{mg} / \mathrm{L}$. The MP concentrations tested herein were considered relatively high, considering the EU legislation limiting such concentrations to values of $0.1 \mu \mathrm{g} / \mathrm{L}$ for isolated organophosphorate, and $0.5 \mu \mathrm{g} / \mathrm{L}$ for pesticide groups in drinking water (INGELSE et al., 2001).

\section{Assays in batch reactors}

Figure 1 shows the concentration of MP in the batch reactors (PF) over time. Clearly, Aspergillus niger was able to remove MP from the liquid phase, since all reactors inoculated with the fungus showed a

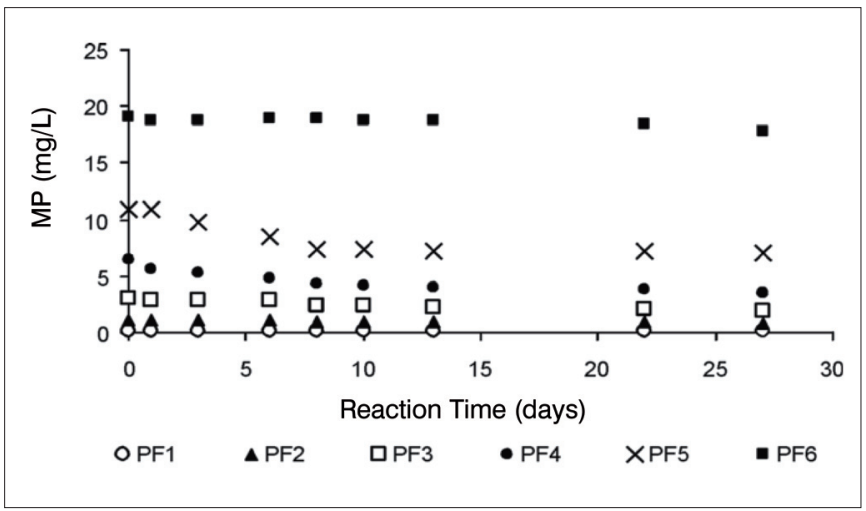

Figure 1 - Variation of MP concentration as a function of the reaction time in the PF reactors. drop in the MP concentration during the experiment, while the control reactors maintained the same MP concentration throughout the experiment. The inhibitory effect of MP on the removal efficiency was also clear, i.e., the reactors with initial MP concentration of $0.2 \mathrm{mg} / \mathrm{L}$ displayed a removal efficiency of 51\% after 27 days, while the PF6, which is a reactor with an initial MP concentration of $19.1 \mathrm{mg} / \mathrm{L}$, removed only $2 \%$.

Figure 2 shows the beneficial effect on the MP removal rate resulting from the addition of glucose. The highest removal efficiency was $82 \%$, which was achieved by the reactor with the lowest initial concentration $(0.62 \mathrm{mg} / \mathrm{L})$. Inhibition due to the insecticide was also evident, for the removal efficiency increased at a lower initial MP concentration; in other words, the highest initial concentration tested $(24.89 \mathrm{mg} / \mathrm{L})$ resulted in a removal efficiency of $43 \%$. According to Griffin (1994), glucose presence reduces the lag phase, hastening the exponential growth phase.

The enzymatic action of the fungus may have been responsible for the degradation of MP. This fungus possesses several enzymatic systems, such as: glucose oxidase, catalase, lactanase (WITTEVEEN, 1993), cytochrome P450 monooxygenase and ligninolytic enzymes (PRENAFETA BOLDÚ, 2002).

Cytochrome P450 monooxygenase is coupled to NADPH reductase, which works as a source of electrons for oxidation reactions. Its system plays a central role in the oxidative metabolism, as well as in the detoxification of xenobiotics. The enzyme catalyses the epoxidation of the aromatic ring, producing arene oxides that are formed through the epoxide hydrolase trans-dihydrodiols or are rearranged nonenzimatically to form phenols (PRENAFETA BOLDÚ, 2002). Therefore, this enzymatic system must have been activated, promoting the partial degradation of MP.

In a oxidation study of ten organophosphorate pesticides, including MP mediated by the enzyme chloroepoxidase, starting from the fungus Caldaromyces fumago, Hernandez et al. (1998) transformed seven of the ten pesticides into their oxone forms. In this study, the authors found similarities with cytochrome P450 action but, unlike

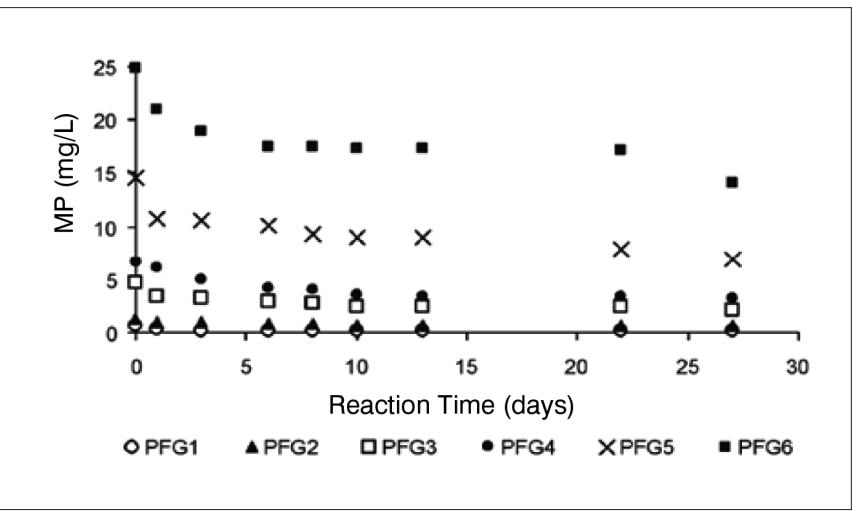

Figure 2 - Variation of MP concentration as a function of the reaction time in the PFG reactors. 
citocrome P450, the chloroperoxidase was not capable of cleaving the oxone structures.

The influence of glucose on MP degradation can also be evaluated through a kinetic study. The initial Ro values were obtained from the temporal profiles of MP concentration, resulting from several initial MP concentrations (Equation 1). The values of Ro are presented in Table 2, and data for control reactors are not shown.

The first-order kinetic model represented well the MP degradation rate data, as shown in Equation 2.

$$
R=K_{1} C_{M P}
$$

Equation 2

Where:

$\mathrm{R}$ is the overall conversion rate of MP;

$\mathrm{C}_{\mathrm{MP}}$ is MP concentration; and

$\mathrm{k}_{1}$ is the first order kinetic constant.

The kinetic constant in the experiments without glucose was $0.063 \pm 0.005 h^{-1}$, and with glucose, $0.162 \pm 0.014 h^{-1}$. Therefore, we can state unequivocally that the addition of glucose increased the MP conversion rate.

The cellular production in the PFG reactors was around $80 \%$ (Figure 3), except for PFG6, which contained a higher concentration of MP. The PF reactors showed a decrease in the biomass production with a MP concentration that is increasing. Thus, the addition of glucose led to a different behavior than the one displayed by the reactors without glucose, indicating that, in the range of MP concentrations from 0.62 to $14.52 \mathrm{mg} / \mathrm{L}$, the cellular growth was practically the same.

It is assumed that glucose can be indispensable both for the removal of MP and for cellular growth. However, it is necessary to apply statistical test to affirm the importance of the glucose addition for the MP removal.

\section{Conclusions}

MP concentrations of up to $60 \mathrm{mg} / \mathrm{L}$ were not toxic to Aspergillus niger AN400. The presence of a glucose concentration of $0.5 \mathrm{mg} / \mathrm{L}$ helped the removal of the pollutant.
Table 2 - Initial reaction rate (Ro) of MP degradation for reactors with (PFG) and without (PF) glucose

\begin{tabular}{|cccc|}
\hline \multicolumn{2}{|c}{ PF (without glucose) } & \multicolumn{2}{c|}{ PFG (with glucose) } \\
\hline MP (mg/L) & Ro (mg/L.h) & MP (mg/L) & Ro (mg/L.h) \\
\hline 0.210 & 0.0380 & 0.620 & 0.710 \\
1.250 & 0.0516 & 1.250 & 0.238 \\
\hline 3.060 & 0.0861 & 4.670 & 1.034 \\
6.100 & 0.4692 & 6.530 & 0.695 \\
10.930 & 0.6783 & 14.520 & 2.806 \\
\hline 19.140 & $*$ & 24.890 & 3.786 \\
\hline
\end{tabular}

* The reaction rate could not be determined based on data obtained under this condition.

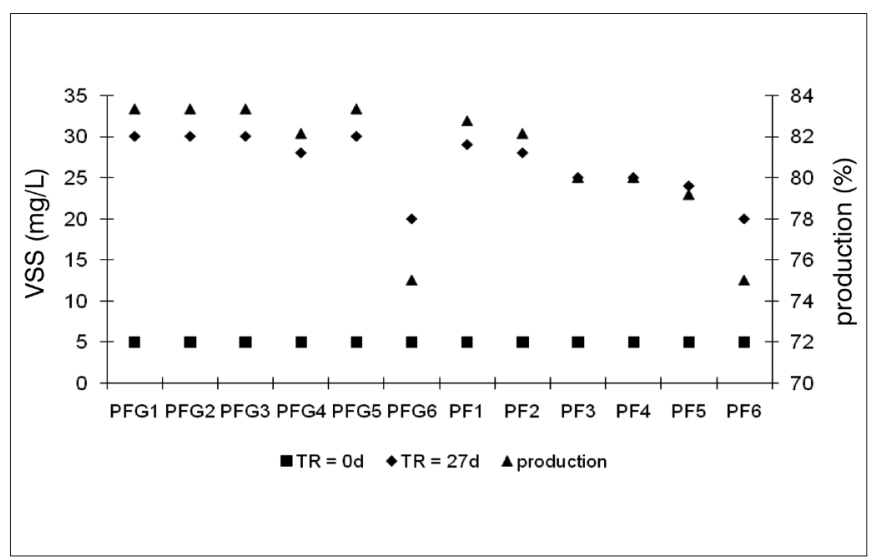

Figure 3 - VSS profile in the PF and PFG reactors.

The highest MP removal rate achieved was $82 \%$ in the PFGlreactor, which was loaded with the lowest initial MP concentration of the group $(0.062 \mathrm{mg} / \mathrm{L})$. Therefore, the presence of glucose was indispensable for MP removal.

The first order kinetic model well-represented the rate of MP degradation, particularly in the reactors containing glucose. The kinetic constant in the experiments without added glucose was $0.063 \pm$ $0.005 \mathrm{~h}^{-1}$ and in those with glucose, $0.162 \pm 0.014 \mathrm{~h}^{-1}$, indicating that the addition of glucose hastened the conversion of MP.

The cell growth in the PFG reactors was not affected by the increase in MP up to a concentration of $14.52 \mathrm{mg} / \mathrm{L}$, but it was declined at an MP concentration of $24.89 \mathrm{mg} / \mathrm{L}$. In the PF reactors, the cell growth decreased as the MP concentration increased.

\section{References}

AGRIPEC. RELATÓRIO TÉCNICO - Distribuição de vendas (2000). AGRIPEC - Química e Farmacêutica S/A.

RELATÓRIO TÉCNICO Folisuper 600 BR (1987). AGRIPEC Química e Farmacêutica S/A.
APHA. Standard methods for the examination of water and wastewater. $20^{\text {th }}$ ed. Washington: American Public Association, 1998, 936 p.

BOUSSAHEL, R. et al. Removal of pesticides residues in water using the nanofiltration process. Desalination, v. 132: p.205-209, 2000. 
BRUCE, C. A.; BRUCE, E. L.; ROBERT, L.G. Degradation of pentachlorophenol by fixed films of white rot fungi in rotating tube bioreactors. Water Research, v. 29, n. 1, p. 61-6, 1995.

ESPINDOLA, E. L. G. et al. Ecotoxicologia: Perspectivas para o século XXI, v. 1. São Carlos: RiMA, 2000.

GARCIA, I. G. et al. Removal of phenol compounds from olive mill wastewater using Phanerochaete chrysosporium, Aspergillus niger, Aspergillus terreus and Geotrichum candidum. Process Biochemistry, v. 35, p. $751-758,2000$.

GRIFFIN, D. H. Fungal physiology. 2nd ed. New York: Wiley-Liss, 1994. 458p.

HERNANDEZ, J. et al. Chloroperoxidase-mediated oxidation of organophosphorus pesticides. Pesticides Biochemistry and Physiology, v. 61, p. 87-94, 1998.

INGELSE, B.A. etal. Determination of polar organophosphorus pesticides in aqueous samples by direct injection using liquid chromatography tandem mass spectrometry. Journal of Chromatography, v. 918, n. 1, p. 67-78, 2001.

IPCS International Program of Chemical Safety Health and Safety Guide no. 75 (1992), World Health Organization, Geneva.

LUCHINI, L. C.; PERES, T. B.; REZENDE, M. O. Degradation of the insecticide parathion in methanol by gamma-irradiation. Journal of Radioanalytical and Nuclear Chemistry, v. 241, n. 1, p. 191-194, 1999.

MA, J.; GRAHAM, N. J. D. Degradation of atrazine by manganesecatalysed ozonation influence of radical scavengers. Water Research, v. 34, p. 3822-3828, 2000.

MARQUARDT, D.W. An algorithm for least-squares estimation of non-linear parameters. Journal of the Society for Industrial Applied Mathematics. v. 11, n. 2, p. 431-441, 1963.

MARTíN-GULLÓN, I.; FONT, R. Dynamic pesticide removal with activated carbon fibers. Water Research, v. 35, p. 516-520, 2001.

PAL, O. R.; VANJARA, A. K. Removal of malathion and butachlor from aqueous solution by clays and organoclays. Separation and Purification Technology, v. 24, p. 167-172, 2001.

PINHEIRO, Z. B. et al. Remoção biológica de fenol por uso de reator contínuo com inóculo de Aspergillus niger. Revista Engenharia Sanitária, v. 15, n. 1 , p. $47-52,2010$.
PRENAFETA BOLDÚ, F. X. Growth of on aromatic hydrocarbons: environmental technology perspectives. The Netherlands: Thesis Wageningen University; 2002.

RODRIGUES, K. A. et al. Viabilidade do tratamento de água residuária sintética têxtil em reator aeróbio de leito fixo. Revista Engenharia Sanitária v. 15, n. 1 , p. $99-106,2010$

RODRIGUES, K. A. et al. Influência da glicose sobre o consumo de fenol por Aspergillus niger AN400 em reatores em batelada. Revista Engenharia Sanitária, v. 12, n. 2, p. 222-228, 2007.

SAMPAIO, G. M. M. S. Remoção de metil paration e atrazina em reatores com fungos. Tese (Doutorado em Hidráulica e Saneamento) - Escola de Engenharia de São Carlos, Universidade de São Paulo, São Carlos, 2005.

SANTOS, F. F.; REZENDE, M. O. Degradação acelerada do inseticida paration etílico utilizando radiação ultravioleta na presença de ácido húmico. In: Anais Associação Brasileira de Química, v. 48, p. 86-91, 1999

SILVA, I. E. C. et al. Fungos filamentoso degradadores de compostos fenólicos de água residuária de postos de combustíveis. Biology and Health Journal, v. 1. n.1. p. 123-130, 2007.

SINDAG - SINDICATO NACIONAL DA INDÚSTRIA DE PRODUTOS PARA DEFESA AGRÍCOLA. Disponível em: http:// www.sindag.com.br. Accesso em 9 outubro 2003.

SINGH, H. Mycorremediation. New Jersey: John Wiley \& Sons, 2006. $592 p$

SUDO, M.; KUNIMATSU, T.; OKUDO, T. Concentration and loading of pesticide residues in Lake Biwa basin (Japan). Water Research, v. 36 , p. 315-329, 2002

VOLKE-SPULVEDA, T. L.; GUTIERREZ-ROJAS, M.; FAVELATORRES, E. Biodegradation of hexadecane in liquid and solid-state fermentations by Aspergillus niger. Bioresourse Technology, v. 87, p. 81-86, 2003.

YANG, Q. et al. Degradation of synthetic reactive azo dyes and treatment of textile wastewater by a fungi consortium reactor. Biochemical Engineering Journal, v. 43, p. 225-230, 2008.

WITTEVEEN, COR F. B. Gluconato formation and polyol metabolism in Aspergillus niger. Thesis Wageningen University, Wagenningen, The Netherlands, 1993. 